NBSIR 83-2706

\title{
Fire Research Publications, 1982
}

U.S. DEPARTMENT OF COMMERCE

National Bureau of Standards

National Engineering Laboratory

Center for Fire Research

Washington, DC 20234

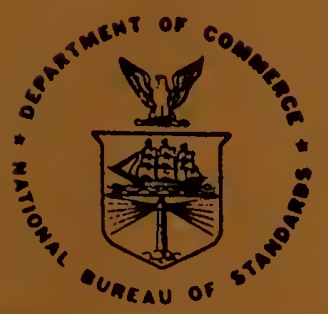

U.S. DEPARTMENT OF COMMERCE NATIONAL BUREAU OF STANDARDS 

FIRE RESEARCH PUBLICATIONS, 1982

Nora H. Jason

U.S. DEPARTMENT OF COMMERCE

National Bureau of Standards

National Engineering Laboratory

Center for Fire Research

Washington, DC 20234

May 1983

U.S. DEPARTMENT OF COMMERCE, Maicolm Baldrige, Secretary NATIONAL BUREAU OF STANDARDS, Ernest Ambler, Director 

"Fire Research Publications, 1982" is a supplement to the previous editions:

$\begin{array}{llll}1969-72 & \text { NBSIR 73-246 } & \text { NTIS Order No. } & \text { COM-74-10989 } \\ 1973 & \text { NBSIR 74-511 } & & \text { COM-74-11448 } \\ 1974 & \text { NBSIR 75-736 } & \text { COM-75-11018 } \\ 1975 & \text { NBSIR 76-1120 } & \text { PB-257837 } \\ 1976 & \text { NBSIR 77-1277 } & \text { PB-269965 } \\ 1977 & \text { NBSIR 78-1504 } & \text { PB-284462 } \\ 1978 & \text { NBSIR 79-1745 } & \text { PB-295395 } \\ 1979 & \text { NBSIR 80-2114 } & \text { PB80-103335 } \\ 1980 & \text { NBSIR 81-2272 } & \text { PB81-203317 } \\ 1981 & \text { NBSIR 82-2499 } & \text { PB82-220104 }\end{array}$

Only publications prepared by members of the Center for Fire Research (CFR), by other National Bureau of Standards (NBS) personnel for CFR, or by external laboratories under contract or grant from the CFR are cited.

For documents that are available for purchase from either the Government Printing office (GPO) or the National Technical Information Service (NTIS), the specific order number has been included in the citation.

GPO documents are obtained by writing directly to the Superintendent of Documents, U.S. Government Printing office, Washington, DC 20402. Indicate the SD Catalog No. or Stock No. for each document requested. Orders must be prepaid. Remittance should be made by check or noney order payable to the "Superintendent of Documents, U.S. Government Printing office".

NTIS documents are obtained by writing directly to the National Technical Information Service, Springfield, VA 22161. Indicate the NTIS Order No. for each document requested. Microfiche copies of the documents also are available at a cost of $\$ 4.50$ for domestic orders. All prices are subject to change. However, for your convenience, a partial price list is provided below. Orders must be prepaid by check or money order payable to "National Technical Information Service" or by utilizing your NTIS deposit account.

\begin{tabular}{lr} 
Page Range & Price \\
\hline $001-025$ & $\$ 7.00$ \\
$026-050$ & 8.50 \\
$051-075$ & 10.00 \\
$076-100$ & 11.50 \\
$101-125$ & 13.00 \\
$126-150$ & 14.50 \\
$151-175$ & 15.00 \\
$176-200$ & 17.50 \\
$201-225$ & 19.00
\end{tabular}


TABLE OF CONTENTS

Page

I. Journal Articles and Conference Proceedings $\ldots \ldots \ldots \ldots \ldots \ldots$ l

II. National Bureau of Standards Publications

A. National Bureau of Standards Interagency Reports ...... 5

B. National Bureau of Standards Special Publication ....... 8

III. Contract and Grant Reports $\ldots \ldots \ldots \ldots \ldots \ldots \ldots \ldots \ldots \ldots \ldots$

IV . Author Index $\ldots \ldots \ldots \ldots \ldots \ldots \ldots \ldots \ldots \ldots \ldots \ldots \ldots \ldots \ldots \ldots \ldots$ 


\section{Journal Articles}

Babrauskas, V. Performance of the Ohio State University Rate of Heat Release Apparatus Using Polymethylmethacrylate and Gaseous Fuels. Fire Safety Journal, Vol. 5, No. 1, 9-20, 1982.

Babrauskas, V. Will the Second Item Ignite? Fire Safety Journal, Vol. 4, No. 4, 281-292, 1981/1982.

Baum, H.R. and Rehm, R.G. Numerical Computation of Large-Scale Fire-Induced Flows. Presented at the Eighth International Conference on Numerical Methods in Fluid Dynamics, Aachen, West Germany, June 28-July 2, 1982.

Baum, H.R. and Rehm, R.G. Numerical Computation of Large-Scale Fire-Induced Flows. In: Lecture Notes in Physics, Vol. 170, New York, Springer Verlag, 1982 p. 142 .

Baum, H.R., Rehm, R.G., and Mulholland, G.W. Prediction of Heat and Smoke Movement in Enclosure Fires. In: Eighth International Conference on Problems of Automatic Fire Detection, Duisbury, W. Germany, October 5-7, 1982, Proceedings.

Baum, H.R., Rehm, R.G., and Mulholland, G.W. Computation of Fire-Induced Flow and Smoke Coagulation. In: 19th Symposium (International) on Combustion, Philadelphia, Combustion Institute, 1982, pp. 921-931.

Bel1, J.R. Investigation Report of the Fire at Stouffer's Inn of Westchester Harrison, New York. Fire Journa1, Vol. 76, No. 3, 37-41, 44-49, 52-54, May 1982.

Bell, J.R., Klem, T.J., and Wiley, A.E. Twelve Die in Fire at Westchase Hilton Hotel Houston, Texas. Fire Journal, Vol. 77, No. 1, 11-15, 20-23, 54-57, January 1983.

Be11, J.R., Klem, T.J., and Wiley, A.E. Westchase Hilton Investigation. Fire Service Today, Vol. 50, No. 1, 12-17, January 1983.

Berlin, G.N., Dutt, A., and Gupta, S.M. Modeling Emergency Evacuation from Group Homes. Fire Technology, Vol. 18, No. 1, 38-48, February 1982.

Bryan, J.L. Human Behavior in the MGM Grand Hotel Fire. Fire Journal, Vo1. 76, No. 2, 37-41, 44-48, March 1982 .

Chalmet, L.G., Francis, R.L., and Saunders, P.B. Network Models for Building Evacuation. Fire Technology, Vol. 18, No. 1, 90-113, February 1982.

Chapman, R.E. and Hall, W.G. Code Compliance at Lower Costs: A Mathematical Programming Approach. Fire Technology, Vol. 18, No. 1,77-89, February 1982.

Cooper, L.Y., Harkleroad, M•, Quintiere, J., and Rinkinen, W. An Experimental Study of Upper Hot Later Stratification in Full-Scale Multiroom Fire Scenarios. Journal of Heat and Transfer, Vol. 104, 741-749, November 1982. 
Cooper, L.Y. A Mathematical Model for Estimating Available Safe Egress Time in Fires. Fire and Materials, Vol. 6, Nos. 3\&4, 135-144, September/ December 1982 .

Cooper, L.Y. Heat Transfer From a Buoyant Plume to an Unconfined Ceiling. American Society of Mechanical Engineers Transactions, Journal of Heat Transfer, Vol. 104, 446-451, August 1982.

Damant, G.H., Williams, S.S., and Krasny, J.F. Cigarette Ignition Behavior of Commercial Upholstery Cover Fabrics. Journal of Consumer Product Flammability, Vol. 9, No. 1, 31-46, March 1982.

Earl, W.L. and VanderHart, D.L. Measurement of ${ }^{13} \mathrm{C}$ Chemical Shifts in Solids. Journal of Magnetic Resonance, Vol. 48, 35-54, 1982.

Evans, D.D. Sprinklers Come Home at Last. Fire Service Today, Vol. 49, No. 10, 14-16, October 1982 .

Gann, R.G. and Manka, M.J. Ignitability of Decomposed Transformer Fluids . Fire Technology, Vol. 18, No. 3, 251-258, August 1982.

Gann, R.G., Ear1, W.L., Manka, M.J., and Miles, L.B. Research Clarifies Anti-Smoldering Role of Sulphur. Sulphur Research \& Development, Vol. 5, p. 19,1982 .

Gomberg, A. and Hall, J.R. Space Heater-Rural Death Link. Fire Service Today, Vol. 49, No. 9, 18-21, September 1982.

Gross, D. Progress on Fire Safety Standards - Fire Standards Activities in ASTM. Fire and Materials, Vol. 5, No. 4, 177-178, 1981.

Hill, S.W. and Best, R. Fires in Two Boarding Facilities Kill 34 Residents. Fire Journal, Vol. 76, No. 4, 44-49, 51-57, 106, July 1982.

Jaluria, Y. Fire Plume Penetration into the Hot Upper Layer in a Room Fire. Presented at the Combustion Institute, Eastern States Section, Atlantic City, NJ, December 12-14, 1982.

Jaluria, Y. and Steckler, K.D. Wall Flow Due to Fire in a Room. Presented at the Combustion Institute, Eastern States Section, Atlantic City, NJ, December 12-14, 1982 .

Jones, W.W. An Infrared Numerical Method for Fire Modules. Presented at the Combustion Institute, Eastern States Section, Atlantic City, NJ, December $12-14,1982$.

Kashiwagi, T. Effects of Sample Orientation on Radiative Ignition. Combustion and Flame, Vo1. 44, 223-245, 1982.

Kashiwagi, T. and Kashiwagi, T. A Study of the Radiative Ignition Mechanism of a Solid Fuel Using Holographic Interferometry. Presented at the AIAA 20 th Aerospace Sciences Meeting, Orlando, Florida, January 11-14, 1982. 
Kashiwagi, Takao and Kashiwagi, Takashi A Study of the Radiative Ignition Mechanism of a Liquid Fuel Using High Speed Holographic Interferometry . In: 19th Symposium (International) on Combustion, Philadelphia, Combustion Institute, 1982, pp. 1511-1521.

Kashiwagi, T., Ohlemiller, T.J., and Kashiwagi, T. Observation of Vapor Generation Preceding the Ignition of Liquid n-Decane and I-Decene by $\mathrm{CO}_{2}$ Laser Radiation. Combustion Science and Technology, Vol. 29, 15-35, 1982.

Kashiwagi, T. and Ohlemiller, T.J. A Study of Oxygen Effects on Nonflaming Transient Gasification of PMMA and PE During Thermal Irradiation. In: 19 th Symposium (International) on Combustion, Philadelphia, Combustion Institute 1982, pp. 815-823.

Keating, J.P. Myth of Panic. Fire Journal, Vol. 76, No. 3, 57-58, 60-61, 147, May 1982 .

Krasny, J.F. Flammability Evaluation Methods for Textiles. Flame-Retardant Polymeric Materials, Vol. 3, edited by M. Lewin, S.M. Atlas, and E.M. Pearce, New York, Plenum Publishing Corp., 1982, pp. 155-200.

Krasny, J.F. and Braun, E. Textile Flammability Testing: Appropriate Levels for Moisture Content of Specimens. Fire and Materials, Vol. 6, No. 1, 38-41, March 1982.

Krasny, J.F., Singleton, R.W., and Pettengil1, J. Performance Evaluation of Fabrics Used in Fire Fighters' Turnout Coats. Fire Technology, Vol. 18, No. 4, 309-318, November 1982 .

Kulkarni, A.K. and Sibulkin, M. Burning Rate Measurements on Vertical Fuel Surfaces. Combustion and Flame, Vol. 44, 185-186, 1982.

Levin, B.M. and Nelson, H.E. A Measure of Evacuation Difficulty. In: 6th International Fire Protection seminar, Karlsruhe, W. Germany, September 21-24, 1982, Proceedings, pp. 323-332.

Levin, B., Paulsen, R. and Klote, J. Fire Safety. Access Information Bulletin 1981 .

Levin, B.C. Fire Deaths and Toxic Gases. Nature, Vo1. 300, No. 5887, 18 , November 4, 1982 .

Mallard, W.G., Miller, J.H., and Sinyth, K.C. Resonantly Enhanced Two-Photon Photoionization of NO in an Atmospheric Flame. Journal of Chemical Physics, Vol. 76, No. 7, 3483-3492, April 1, 1982.

Mallard, W.G. and Smyth, K.C. Mobility Measurements of Atomic Ions in Flames Using Laser-Enhanced Ionization. Combustion and Flame, Vo1. 44, 61-70, 1982 .

Miller, J.H., Mallard, W.G., and Smyth, K.C. Observation of Laser-Induced Visible Fluorescence in Sooting Diffusion Flames. Combustion and Flame, Vol. 47, No. 2, 205-214, 1982 . 
Mulholland, G.W. How Well Are We Measuring Smoke? Fire and Materials, Vo1. 6, No. 2, 65-67, June 1982.

Mulholland, G. and Ohlemiller, T.J. Aerosol Characterization of a Smoldering Source. Aerosol Science and Technology, No. 1, 59-71, 1982.

Nelson, H.E. Approach to Enhancing the Value of Professional Judgment in the Derivation of Performance Critiera. In: Performance Concept in Building, Third ASTM/CIB/RILEM Symposium, diskon, March 29-April 2, 1982. Proceedings, pp. 55-64.

Nelson, H.E. Fire Safety Equivalency System for Overnight Accommodations, Trends, Vol. 19, No. 2, 31-36, 1982.

Ohlemiller, T. and Lucca, D. Experimental Comparison of Forward and Reverse Smolder Propagation in Permeable Fuel Beds. Presented at the Combustion Institute, Western States Section, Salt Lake City, Utah, April 1982.

Ohlemiller, T.J. Cellulosic Insulation Materials. Part 3. Effects of Heat Flow Geometry on Smolder Initiation. Combustion Science and Technology, Vo1. 26, No. $3 \& 4,89-105,1981$.

Paabo, M., Birky, M.M., and Womble, S.E. Analysis of Hydrogen Cyanide in Fire Environments. Journal of Combustion Toxicology, Vo1. 6, 99-108, May 1979.

Perkins, R.M. Insulative Values of Single-Layer Fabrics for Thermal Protective Clothing. Textile Research Journal, Vo1. 49, 202-212, 1979.

Rehm, R.G., Baum, H.R., and Barnett, P.D. Buoyant Convection Computed in a Vorticity, Stream-Function Formulation. Journal of Research of NBS, Vo1. 87, No. 2, 165-185, March-April 1982.

Robertson, A.F. Development of an Improved Radiant Heat Source for Fire Testing. Fire and Materials, Vol. 6, No. 2, 68-72, June 1982.

Rockett, J.A. Modeling of NBS Mattress Tests with the Harvard Mark V Fire Simulation. Fire and Materials, Vol. 6, No. 2, 80-95, June 1982.

Schmidt, W. and Klote, J. In Case of Fire--Use the Stairwells, Elevators Aren't Safe. Specifying Engineer, Vo1. 47, No. 5, 82-86, May 1982.

Shafizadeh, F., Bradbury, A.G.W., DeGroot, W.F., and Aanerud, T.W. Role of Inorganic Additives in the Smoldering Combustion of Cotton Cellulose. Industrial Engineering Chemistry Product Research Development, Vo1. 21 , No. $1,97-101,1982$.

Sibulkin, M., Kulkarni, A.K., and Annamalai, K. Burning on a Vertical Fuel Surface with Finite Chemical Reaction Rate. Combustion and Flame, Vol. 44, 187-199, 1982 .

Sibulkin, M. and Malary, S.F. Diffusion Flame Calculations for Nonunity Lewis Number. Combustion Science and Technology, Vol. 28, 85-88, 1982. 
Smyth, K., Lias, S.G., and Ausloos, P. The Ion-Molecule Chemistry of $\mathrm{C}_{3} \mathrm{H}_{3}^{+}$ and the Implications for Soot Formation. Combustion Science and Technology, Vol. 28, No. $3 \& 4,147-154,1982$.

Smyth, K.C. and Mallard, W.G. Laser-Induced Ionization and Mobility Measurements of Very Small Particles in Premixed Flames at the Sooting Limit. Combustion Science and Technology, Vol. 26, No. $3 \& 4,35-41$, 1981 .

Smyth, K.C. and Mallard, W.G. Two-Photon Ionization Processes of PO in a $\mathrm{C}_{2} \mathrm{H}_{2}$ /Air Flame. Journal Chemical Physics, Vol. 77, No. 4, 1779-1787, August 13,1982 .

Stahl, F.I. BFIRES-II: A Behavior Based Computer Simulation of Emergency Egress During Fires. Fire Technology, Vo1. 18, No. 1, 49-65, February 1982 .

Steckler, K.D., Quintiere, J.G., and Rinkinen, W.J. Flow Induced by Fire in a Compartment, In: 19th Symposium (International) on Combustion. Philadelphia, Combustion Institute, 1982, pp. 913-920.

Waksman, D. and Walton, W.D. Fire Testing of Solar Collectors by ASTM E 108. Fire Technology, Vol. 18, No. 2, 174-186, May 1982.

Williams, F.A. Urban and Wildland Fire Phenomenology. Progress in Energy and Combustion Science, Vol. 8, No. 4, 317-354, 1982.

Wong, K.L. and Alarie, Y. A Method for Repeated Evaluation of Pulmonary Performance in Unanesthetized, Unrestrained Guinea Pigs and Its Application to Detect Effects of Sulfuric Acid Mist Inhalation. Toxicology and Applied Pharmacology, Vol. 63, No. 1, 72-90, 1982.

You, H-Z. and Faeth, G.M. Turbulent Combustion - Buoyant Axisymmetric Turbulent Diffusion Flames in Still Air. Combustion and Flame, Vol. 44, 261-275, 1982 .

II. National Bureau of St andards Publications

A. National Bureau of Standards Interagency Reports

NBSIR 81-2453 Lee, B.T. Quarter-Scale Modeling of Room Fire Tests of Interior Finish. March 1982. 71 p. NTIS Order No. PB83-159129.

NBSIR 82-2469 Lee, B.T. Ef fect of Ventilation on the Rates of Heat, Smoke, and Carbon Monoxide Production in a Typical Jail Cell Fire. March 1982. 80 p. NTIS Order No. PB82-194168.

NBSIR 82-2473 McCaffrey, B.J. and Cox, G. Entrainment and Heat Flux of Buoyant Diffusion Flames. Final Report. February 1982. 35 p. NTIS Order No. PB82-196296. 
NBS IR $82-2480$

Stahl, F.I., Crosson, J.J., and Margulis, S.T. Time-Based Capabilities of Occupants to Escape Fires in Public Buildings: A Review of Code Provisions and Technical Literature. April 1982. 168 p. NTIS Order No. PB82-212887.

NBSIR $82-2488$

Fang, J.B. Fire Endurance Tests of Selected Residential Floor Constructions. May 1982. 113 p. NTIS Order No. PB82-225079.

NBSIR 82-2499 Jason, N.H. Fire Research Publications, 1981. April 1982. 16 p. NTIS Order No. PB82-220104.

NBSIR 82-2503 Lawson, J.R. and Parker, W.J. Development of an Ease of Ignition Test Using a Flame Exposure. June 1982. 64 p. NTIS order No. PB82-252339.

NBSIR 82-2506 Loftus, J.J. Evaluation of Wall Protection Systems for Wood Heating Appliances. May 1982. 61 p. NTIS Order

No. PB82-215088.

NBSIR 82-2507 Klote, J.H. Elevators as a Means of Fire Escape. May 1982. 37 p. NTIS Order No. PB82-230269.

NBSIR 82-2508 Quintiere, J.G. An Assessment of Correlations Between Laboratory and Ful1-Scale Experiments for the FAA Aircraft Fire Safety Program - Part 1: Smoke. July 1982. 52 p. NTIS Order No. PB83-113522.

NBSIR 82-2512 Klote, J.H. A Computer Program for Analysis of Smoke Control Systems. Final Report, June 1982. 69 p. NTIS Order No. PB82-25484.

NBSIR 82-2516 Peacock, R.D. and Breese, J.N. Computer Fire Modeling for the Prediction of Flashover. May 1982. 88 p. NTIS Order No. PB82-245812.

NBSIR 82-2519 Gomberg, A. and Clark, L.P. Rural and Non-Rural Civilian Residential Fire Fatalities in Twelve States. June 1982. 52 p. NTIS Order No. PB82-252032.

NBSIR 82-2520 Steckler, K.D., Quintiere, J.G., and Rinkinen, W.J. Flow Induced by Fire in a Compartment. September 1982. 101 p. NTIS Order No. PB83-107714.

NBSIR 82-2521 Hayes, Jr., W.D. and Zile, R.H. Full-Scale Study of the Effect of Pendent and Sidewall Location on the Activation Time of an Automatic Sprinkler. 74 p. NTIS Order No. PB82-251125.

NBSIR 82-2525 Quintiere, J.G. An Assessment of Correlations Between Laboratory and Full-Scale Experiments for the FAA Aircraft Fire Safety Program - Part 4: Flammability Tests. July 1982. 25 p. NTIS Order No. PB83-113548. 
NBSIR $82-2532$

NBSIR $82-2536$

NBSIR $82-2537$

NBSIR $82-2551$

NBSIR $82-2554$

NBSIR $82-2556$

NBSIR $82-2557$

NBSIR $82-2558$

NBSIR $82-2562$

NBSIR $82-2564$

NBSIR $82-2578$
Levin, B.C., Fowe1l, A.J., Birky, M.M., Paabo, Stolte, A., and Malek, D. Further Development of a Test Method for the Assessment of the Acute Inhalation Toxicity of Combustion Products. June 1982. 143 p. NTIS Order No. PB82-217886.

Quintiere, J.G. An Assessment of Correlations Between Laboratory and Full-Scale Experiments for the FAA Aircraft Fire Safety Program - Part 2: Rate of Energy Release in Fire. 27 p. NTIS order No. PB83-113530.

Quintiere, J.G. and Tanaka, T. An Assessment of Correlations Between Laboratory and Full-Scale Experiments for the FAA Aircraft Fire Safety Progran - Part 5: Some Analyses of the Post Crash Scenario. July 1982. 25 p. NTIS Order No. PB83-113555.

Gomberg, A., Buchbinder, B., and of fensend, F.L. Evaluating Alternative Strategies for Reducing Residential Fire Loss The Fire Loss Model. Interim Report. August 1982. 66 p. NTIS Order No. PB82-263369.

Metz, F.E., Pielert, J.H., Cooke, P.W., and Walton, W.D. Health and Safety Considerations for Passive Solar Heated and Cooled Buildings. August 1982. 65 p. NTIS Order No. PB82-263336.

Quintiere, J., Birky, M., McDonald, F., and Smith, G. An Analysis of Smoldering Fires in Closed Compartments and Their Hazard Due to Carbon Monoxide. July 1982. 42 p. NTIS Order No. PB82-257684.

Quintiere, J.G., Harkleroad, M., and Walton, W. Measurement of Material Fiame Spread Properties. July 1982. 46 p. NTIS Order No. PB83-101931.

Clark, L.P. A Life-Cycle Cost Analysis Methodology for Fire Protection Systems in New Health Care Facilities. July 1982. 41 p. NTIS Order No. PB82-258914.

Nelson, H.E. and Shibe, A.J. A System for Fire Safety Evaluation for Multifamily Housing. Interim Report. September 1982. 159 p. NTIS Order No. PB83-119909.

Parker, W.J. An Assessment of Correlations Between Laboratory and Full-Scale Experiments for the FAA Aircraft Fire Safety Program, Part 3: ASTM E 84. August 1982. 57 p. NTIS Order No. PB83-164251.

Cooper, L.Y. and Stroup, D.W. Calculating Available Safer Egress Time (ASET) -- A Computer Program and User's Guide Final Report, September 1982. 137 p. NTIS Order No. PB83-117176. 
NBSIR 82-2596

NBSIR $82-2600$

NBSIR $82-2604$

NBSIR $82-2611$

NBSIR $82-2612$

NBSIR $82-2622$

NBSIR $82-2634$
Stiefel, S.W. Use of Decision Analysis in Arson Program Planning. November 1982. 22 p. NTIS Order No. PB83-146944.

Chapman, R.E. A Cost-Conscious Guide to Fire Safety in Health Care Facilities. December 1982. 65 p. NTIS Order

No. PB83-150466.

Babrauskas, V., Lawson, J.R., Walton, W.D., and Twilley, W.H. Upholstered Furniture Heat Release Rates Measured with a Furniture Calorimeter. December 1982. 73 p. NTIS Order No. PB83-165050.

Babrauskas, V. Development of the Cone Calorimeter -- A Bench-Scale Heat Release Rate Apparatus Based on Oxygen Consumption. November 1982. 84 p. NTIS Order No. PB83-151266.

Cherry, S.M. Sixth Annual Conference on Fire Research. Final Report, November 1982. 182 p. NTIS Order No. PB83-155887.

Cooper, L.Y. The Development of Hazardous Conditions in Enclosures with Growing Fires. December 1982. 32 p. NTIS Order No. PB3 164368.

Sne11, J.E., Levin, B.C., and Fowe11, A.J. Workshop on Combustion Product Toxicity Summary of Presentations, September 10, 1982. November 1982, Issued January 1983. 65 p. NTIS Order No. PB83-157479.

B. National Bureau of Standards Special Publication

NBS-SP 639
Chidester, J.E., ed. Fire Research and Safety. Proceedings of the Fifth Joint Panel Meeting of the U.S.-Japan Cooperative Program in Natural Resources held October 15-24, 1980, at the National Bureau of St andards, Gaithersburg, MD. Is sued September 1982. 394 p. GPO Stock No. 003-003-02413-9.

Individual Papers:

Saito, F. Recent Development in Fire Retardance pp. 2-10

Clarke, F. Recent Advances in Flame Retardance Research pp. $11-16$

Wakamatsu, T. and Morishita, Y. Building Systems and Smoke Control pp. 17-21

Benjamin, I. Detection in U.S.A. pp. 22-25

Horiuchi, S. and Jin, T. Human Behavior pp. 26-30

Miyama, J. Fire Detection and Smoke Property pp. 31-38 
Karchmer, C. Early Intervention in Arson Epidemics: Developing a Motive-Based Intervention Strategy pp. 44-63

Kawamura, T. Incendiary Fires in Japan pp. 64-66

Kishitani, K., Saito, F., and Yusa, S. Basic Concept of Toxic Hazards in Building Fires pp. 72-87

Birky, M. Preliminary Comparison of Combustion Model in Toxicity Test Method with a Large-Scale Fire Scenario pp. 88-103

Nishimaru, Y. and Tsuda, Y. Study of Toxic Gas Generated During Combustion--In Case of Natural and Artificial Down pp. 104-121

0'Neill, J. Life Safety Factors Involved in the Use of Sprinklers pp. 122-154

Unoki, J. Sprinkler Technology and Design in Japan Pp. 156-175

Kung, H. Advances in Residential Sprinklers pp. 176-224

Kinoshita, C. and Pagni, P. Laminar Wake Flame Heights pp. $231-235$

Emmons, H. Computer Fire Code pp. 236-247

Friedman, R. Recent U.S. Progress in Mathematical Modeling of Fire Enclosures pp. 248-259

Ohlemiller, T. Modeling of Smoldering Combustion Propagation pp. 266-307

Handa, T. et al. Thermal Processes in the Smoldering of Wood pp. 308-364

III. Contract and Grant Reports

FMRC J.I OEOJ4.BU Beier, R.A., deRis, J., and Baum, H. Accuracy of Finite Difference Methods in Recirculating Flows. RC82-BT-7.

Factory Mutual Research Corp., Norwood, MA, September 1982.

NBS-GCR-82-367 Jeng, S-M., Chen, L-D., and Faeth, G.M. An Investigation of Axisymmetric Buoyant Turbulent Diffusion Flames. October 1981. Issued January 1982. 87 p. NTIS Order No. PB82-165176.

NBS-GCR-82-368 Terpstra, W.R., Jorgenson, M.L., and Dosedlo, L.J . Investigation of Fire Hazards of Fireplace Inserts in FactoryBuilt and Masonry Fireplaces. January 1982. 81 p. NTIS Order No. PB82-184045. 
NBS-GCR-82-377 Carrier, G., Fende11, F., and Fink, S. Towards Wind-Aided Flame Spread Along a Horizontal Charring Slab: The SteadyFlow Problem. November 1981. Issued February 1982. 86 p. NTIS Order No. PB82-183732.

NBS-GCR-82-381 Farrar, D.G., Hileman, F.D., Blank, T.L., and Pope, D.L. Study on the Sensitivity of the Leg-Flexion Avoidance Response to the Sensory Irritant Component of Douglas Fir Combustion Products. March 1982. 56 p. NTIS Order No. PB83-174425.

NBS-GCR-82-383 Kennett, E.W., editor Proceedings of the 1980 Conference on Life Safety and the Handicapped. Howard University, Washington, DC. October 26-29, 1980. Issued March 1982. 116 p. NTIS Order No. PB82-194515.

Individual Papers:

Burgun, J.A. Life Safety Codes pp. 12-13

Benjamin, I. Life Safety Code--Current State of Regulations Providing Safety Considerations in Buildings Accessible to the Handicapped pp. 14-18

Nelson, H.E. 1979 Conference on Life Safety and the Handicapped pp. 19-26

Blizzard, E. Emergency Planning pp. 27-32

Kuns, J. Public Education pp. 33-35

Jameson, F. Notification and Alarm Systems--The Las Vegas Story pp. 36-38

Wilson, R. Fire Protection Strategies pp. 39-45

Favro, P. Implications to Fire Services pp. 46-48

Simon, J.A. Panel on University Concerns--Toward a St ate-of-the-Art pp. 49-50

Callas, G.H. Panel on University Concerns--A Model for Fire and Emergency Evacuation Training pp. 51-52

0'Hara, S. Panel on University Concerns--Fire Safety and Disabled Students at the University of California, Berkeley pp. 54-56

Nicodemus, C. A Case Study pp. 59-61

Dibner, D. Implications for Federal Buildings--Safe Environments--What Does It Take? pp. 62-63

Waldman, P. Mental Disabilities pp. 64-65 
Gangnes, A. Developmental Disabilities pp. 66-71

Lynch, R.J. Compliance pp. 72-73.

NBS-GCR-82-388 Ray, S.R. Flame Spread Over Solid Fuels. May 1982. 224 p. NTIS Order No. PB82-206475.

NBS-GCR-82-392 Fernandez-Pe11o, A.C. Firé Propagation in Concurrent Flow. Final Progress Report - June 1, 1981 to May 31, 1982. June 1982. 24 p. Only available from the Fire Research Information Services.

NBS-GCR-82-395 Tewarson, A. Quantification of Fire Properties of Fuels and Interaction with Fire Environment. June 1982. 37 p. NTIS Order No. PB82-238452.

NBS-GCR-82-396 Borgeson, R.A. Flame Spread and Spread Limits. July 1982. 57 p. NTIS Order No. PB82-258724.

NBS-GCR-82-399 Alleman, J.E., Milke, J.A., and Hickey, H.E. An Investigation of the Water Quality and Condition of Pipe in Existing Automatic Sprinkler Systems for the Analysis of Design with Residential Sprinkler Systems. Final Report. August 1982. 92 p. NTIS Order No. PB83-100263.

NBS-GCR-82-402 Cetegen, B.M., Zukoski, E.E., and Kubota, T. Entrainment and Flame Geometry of Fire Plumes. August 1982. 203 p. NTIS Order No. PB83-107847.

NBS-GCR-82-403 Brauman, S.K. and Chen, I.J. Polymer Degradation During Combustion. Annual Report, Revised. September 1982. 38 p. N'TIS Order No. PB83-110015.

NBS-GCR-82-404 Delichatsios, M.A., Alpert, R.L., Orloff, L., and Mathews, M.K. Computer Modeling of Aircraft Cabin Fire Phenomena. September 1982. 74 p. NTIS Order No. PB83-119891.

NBS-GCR-82-407 Gillen, M. Short-Term Creep of Concrete at Elevated Temperatures. September 1982. 112 p. NTIS Order No. PB83-118117.

NBS-GCR-82-408 Groner, N.E. A Matter of Time--A Comprehensive Guide to Fire Emergency Planning for Board and Care Homes. November 1982. 117 p. NTIS order No. PB83-139345.

NBS-GCR-82-412 Peters, J.W. Studies of Dry-Powder Extinguishment of Diffusion Flames for Condensed Fuels. June 1982. Is sued November 1982. 123 p. NTIS Order No. PB83-150656.

NBS-GCR-82-416 Home Fire Project: 1972-1982. Harvard University, Division of Applied Sciences, Cambridge, MA 02138. November 1982. 49 p. NTIS Order No. PB83-146878. 
NBS-GCR-82-417 Kisko, T.M. and Franc1s, R.L. Network Models of Building Evacuation: Development of Software System. Final Report Year One. December 1982. 13 p. NTIS Order No. PB83-197509. 
A

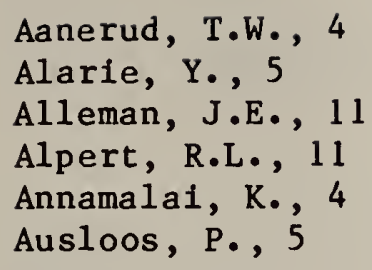

Babrauskas, V., 1,8

Barnett, P.D., 4

Baum, H.R., 1, 4, 9

Beier, R.A., 9

Bell, J.R., 1

Benjamin, I., 8, 10

Berlin, G.N., 1

Best, R., 2

Bi rky, M.M., 4, 7,9

Blank, T.L., 10

Blizzard, E., 10

Borgeson, R.A., 11

Bradbury, A.G.W., 4

Brauman, S.K., 11

Braun, E., 3

Breese, J.N., 6

Bryan, J.L., 1

Buchbinder, B. , 7

Burgun, J.A., 10

C

Callas, G.H., 10

Carrier, G., 10

Cetegan, B.M., 11

Chalmet, L.G., 1

Chapman, R.E., 1,8

Chen, I.J., 11

Chen, L-D., 9

Cherry, S.M., 8

Chidester, J.E., 8

Clark, L.P., 6, 7

Clarke, F., 8

Cooke, P.W., 7

Cooper, L.Y., 1, 2, 7,8

Cox, G., 5

Crosson, J.J., 6
D

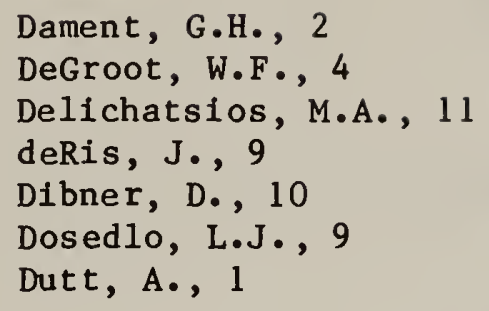

E

Ear1, W.L., 2

Emmons, H., 9

Evans, D.D., 2

F

Faeth, G.M., 5, 9

Fang, J.B., 6

Farrar, D.G., 11

Favro, P., 10

Fende11, F., 10

Fe rnandez-Pello, A.C., 11

Fink, S., 10

Fowe 11, A.J., 7,8

Francis, R.L., 1, 11

Friedman, R., 9

G

Gangnes, A., 11

Gann, R.G., 2

Gillen, M. , 11

Gomberg, A., 2, 6, 7

Groner, N.E., 11

Gross, D., 2

Gupta, S.M., 1

H

Hal1, J.R., 2

Hall, W.G., 1

Handa, T., 9

Harkleroad, M., 1, 7

Hayes, W.D., 6

Hickey, H.E., 11

Hileman, F.D., 10

Hill, S.W., 2

Horiuchi, S., 8 
Morishita, Y., 8

Jaluria, Y., 2

Mulholland, G.W., 1, 4

Jameson, F., 10

$\mathrm{N}$

Jason, N.H., 6

Jeng, S-M., 9

Jin, T., 8

Jones, W.W., 2

Jorgenson, M.L., 9

K

Karchmer, C., 9

Kashiwagi, T., 2, 3

Kawamura, T., 9

Keating, J.P., 3

Kennet t, E.W., 10

Kinoshita, C., 9

Kishitani, K., 9

Kisko, T.M., 11

Klem, T.J., 1

Klote, J., 3, 4, 6

Krasny, J.F., 2, 3

Kubota, T., 11

Kulkarni, A.K. , 3, 4

Kung, H., 9

Kuns, J., 10

L

Nelson, H.E., 3, 4, 7, 10

Nicodemus, C., 10

Nishimaru, Y., 9

\section{0}

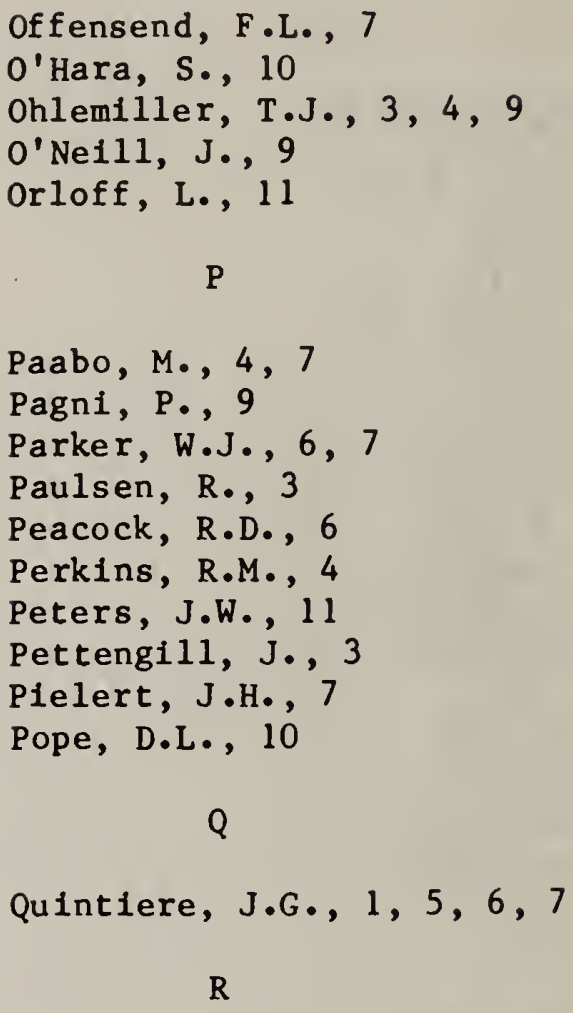

Ray, S.R., 11

Rehm, R.G., 1, 4

Rinkinen, W., $1,5,6$

Robertson, A.F., 4

Rockett, J.A., 4

S

Malary, S.F., 4

Malek, D., 7

Mallard, W.G., 3, 5

Manka, M.J., 2

Margulis, S.T., 6

Mathews, M.K., 11

McCaffrey, B.J., 5

McDonald, F., 7

Metz,F.E., 7

Milke, J.A., 11

Miller, J.H., 3

Miyama, J., 8

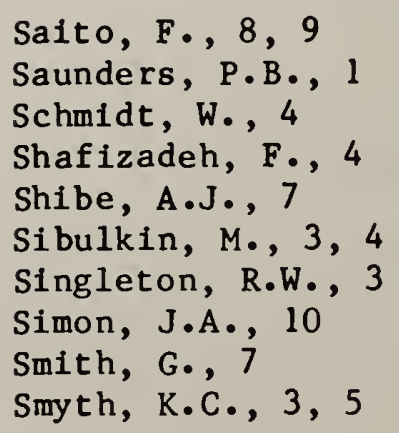




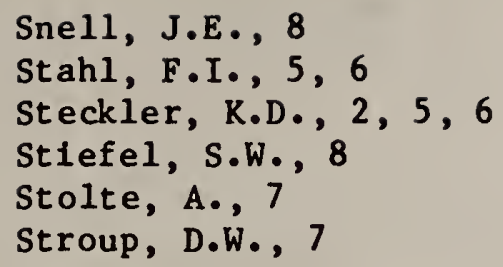


NBS-114A (REV. 2-8C)

\begin{tabular}{|c|c|c|}
\hline $\begin{array}{l}\text { U.S. OEPT. OF COMM. } \\
\text { BIBLIOGRAPHIC DATA } \\
\text { SHEET (See in structions) }\end{array}$ & $\begin{array}{l}\text { 1. PUBLICATION OR } \\
\text { REPORT NO. } \\
\text { NBSIR } 83-2706\end{array}$ & $\begin{array}{r}\text { 2. Performing Organ. Report Nof 3. Publication Date } \\
\text { May } 1983\end{array}$ \\
\hline
\end{tabular}

Fire Research Publications, 1982

5. $\operatorname{AUTHOR}(S)$

Nora H. Jason

6. PERFORMING ORGANIZATION (If joint or other than NBS, see Instructions)

7. ContracVGrant No.

NATIONAL BUREAU OF STANDARDS

DEPARTMENT OF COMMERCE

WASHINGTON, D.C. 20234

9. SPONSORING ORGANIZATION NAME AND COMPLETE ADDRESS (Street, City, Stote, ZTP)

10. SUPPLEMENTARY NOTES

[D Document describes a computer program; SF-185, FIPS Software Summary, is attached.

11. ABSTRACT (A 200-word or less factual summary of most significant information. If document Includes a signiflcant bibliography or literoture survey, mention it here)

"Fire Research Publications, 1982" is a supplement to the previous editions:

$\begin{array}{lll}1969-72 & \text { NBSIR 73-246 } & \text { NTIS Order No. COM-74-10989 } \\ 1973 & \text { NBSIR 74-511 } & \text { COM-74-11448 } \\ 1974 & \text { NBSIR 75-736 } & \text { COM-75-11018 } \\ 1975 & \text { NBSIR 76-1120 } & \text { PB-257837 } \\ 1976 & \text { NBSIR 77-1277 } & \text { PB-269965 } \\ 1977 & \text { NBSIR 78-1504 } & \text { PB-284462 } \\ 1978 & \text { NBSIR 79-1745 } & \text { PB-295395 } \\ 1979 & \text { NBSIR 80-2114 } & \text { PB80-103335 } \\ 1980 & \text { NBSIR 81-2272 } & \text { PB81-203317 } \\ 1981 & \text { NBSIR 82-2499 } & \text { PB82-220104 }\end{array}$

Only publications prepared by members of the Center for Fire Research (CFR), by other National Bureau of Standards (NBS) personnel for CFR, or by external

laboratories under contract or grant from the CFR are cited.

12. KEY WORDS (Six to twelve entries; alphabetical order; capitalize only proper names; and separate key words by semicolons) Bibliographies; building fires; combustion products; compartment fires; egress; fabrid flammability; fire models; fire research; fire tests; flame research; human behavior; smoke; mattresses; toxicity.

13. AVAILABILITY

X. Unlimited

$\square$ For Official Distribution. Do Not Release to NTIS

$\square$ Order From Superintendent of Documents, U.S. Government Printing Office, Washington, D.C. 20402.

14. NO. OF PRINTED PAGES

18

X. Order From National Technical Information Service (NTIS). Springfield, VA. 2216I

15. Price

$\$ 7.00$ 

